\title{
An Analysis of Teacher pedagogical competence in Teaching English at SMK PGRI 3 Kota Serang Clara Suci Shelly ${ }^{1}$, Ida Nuraida ${ }^{2}$, Fadilla Oktaviana ${ }^{3}$ Universitas Banten Jaya Serang, Indonesia clarashelly79@gmail.com ${ }^{1,}$ idanuraida@unbaja.ac.id ${ }^{2}$, fadillaoctaviana@unbaja.ac.id ${ }^{3}$
}

\begin{abstract}
Teacher is one of actor who has the important position to determine the success key of process of learning. Although, the factors that can affects the process of learnnig is not only based on the teacher itself. But as an agent of educator in formal educational institution, the teacher can bring the biggest impact for all of the students. Because as we known, to create the best quality in process of learning, it always need the qualify and professional teacher. There are four competence that should be mastering by teachers, to make themselves be qualify . One of the competence is pedagogical competence. This one, is competence that make the teacher profession is different from the other profesion. This research aimed to describe the ability of teacher in mastering pedagogical competence, and also the process of implementation of pedagogical competence in teaching English at SMK PGRI 3 Kota Serang. This research is one the kind qualitative research with the descriptive approach. To collect data related to the subject that being studied in this research, the writer used some of techniques such as observation, questionnaire, interview and some of the research documentations. This research used three of English teacher as a sample research. For the result of this research it can see based on the result of observation sheet that show is around $65.625 \%$ for the implementation of pedagogical competence in the process of teaching English. And, for the result of questionnaire get the $70 \%$ for score in ability of teacher in mastering pedagogical competence. Based on this research, it can conclude that the ability of teacher in mastering pedagogical competence and implementation of it in teaching English are still include on the good category.
\end{abstract}

Keyword: English teacher, Pedagogical competence, Teaching English. 


\section{INTRODUCTION}

The first, most of students has low interest in learning English. They assume that English is a complicated subject, and they get a difficulty to speak in English, understanding every words in English, or even write sentences in English. Their motivation in learning Eglish is also really less, only few from the students in the class who can follow and understanding English material well. Then, in the final of moment in process of Teaching Internship Program there, the writer tried to do reflection, through asked students in the class to give a suggestion, or even criticsm, based on their opinion, or even what they feel, as long as the process of learning with the writer. And one of them stated that when he learned with his real English teacher, he can't get understand any materials in English that taught his teacher previously. It is ironic to know that student does not get nothing from all the materials that had taught before. Surely, it can give an negative impact for them. Until in the process of assessment that has done by the writer itself, that was conduct on that time, it showed that there are still many students has low mark for English subject. Teacher also has some of specific task to make the successful process of learning, because the successful learning always related to the great, effective or good teachers. Therefore, the writer will try to describe the arguments (Walker 64) related to the some characteristics of effective teachers as follow: Prepared, positive, have a sensitive humour, and display a personal touch and creative.

\section{Definition of Competence}

According to the U.S. Department of Education (DOE), competency-based learning is an action of leads to better student outcomes because the pace of learning is customized to each student. (U.S. Department of Education, 2014). In addition, (Moeheriono 4) defines competence as a basic characteristic of which consists of skills, knowledge and personal attributes more able to distinguish someone who does and does not do. So that, it can define competence is a decisive tool to predict the success of a person working in a certain position.

Charles E. Johnson (Moeheriono 32) explain that competency as a rational performance which satisfactory meets the objective for a desired condition. In this statement showed that through mastering competency, the people can reach the objective or goals that related with the appropriate target's condisition. It means that competency can be a tool that can 
people used to get the situation or goal that they want. Whereas, based on (Darsono 123) “Kompetensi ialah perpaduan keterampilan, pengetahuan, kreativitas, dan sikap positif terhadap pekerjaan tertentu yang diwujudkan dalam kinerja." In English, it means that competency is a collaboration of skills, knowledges, and creativity toward the specific occupation that implemented in a real work's performance. The definiton of competence is also written on Handbook II by Krathwohl, Bloom, and Masia that stated if successfully competency perform for critical the function of works or tasks have to base on works setting defined. It also can apply the use of a set of knowledge related. The potential measurement criteria for competency attainment assessing starting for basic skills standard specify in the competencies often serve in the level of knowledge, skills, and abilities required for success in the workplace well.

\section{The Kinds of Teacher Competences}

Competencies that need to be owned by a lecturer according to Government Regulation no. 19 Year 2005 on National Education Standards, namely :

a. Pedagogical competence, it refers to educational and teaching qualifications. This competence has variety of indicator that should be mastering by a teacher.

b. Personal competence, it refers to personality of lecturer'self. According to (Komara 2) states that personal competence includes steady, noble, wise and prudent, dignified, stable, mature, honest, becoming role models for students and the community, to objectively evaluate their own performance, and develop themselves independently and sustainably.

c. Professional competence can observed through the activity of learning that have done. It is related to the statements by (Endang Asriyanti 142) defines professional competence as the ability of lecturer in mastering the material, concept, and the structure of language.

d. Social competence is required by a person's ability to succeed in dealing with others, including skills in social interaction and social responsibilities (Surya 138 in Hamidi and Indrastuti, 2012) for a lecturer, social competence also needed to support the process of learning.

\section{The Performance of Teacher Professional Competence}

According to (Saud 48) there are $4^{\text {th }}$ generic teaching competences that at least should be 
controlled by a teacher in the actual performance : a). Arrange some of plans for the process of activities in learning and teaching. b).Lead and manage process of teaching and learning. c). Assess the progress on learning activity. d). Mastery of subject matter.

\section{.The Nature of Pedagogical Competence Definition of Pedagogy}

The word of pedagogy has roots in Ancient Greece. Rich Families in Ancient Greece would have many slaves would lead or escort the chidlren to the place of education. The Greek word for child (boy) is pais (the stem of this is 'paid/paedos') and leader is agogus. So a paid-agogus or pedagogue was literally a leader of children. Later, the word of pedagogue becomes synonymous with teaching of young. And currently, the methodology of teaching is called pedagogy. So based on this context, pedagogy is the study of children's education.

\section{The Structure of Pedagogy}

Referring to systematical of pedagogy by Langeveld (Syaripudin \& Kurniasih 19) the systematical of pedagogy can divide into two classes as follow: Theoritical's Pedagogy and Practical's Pedagogy,
According to (Hakim 2) was quoted a theory by Mulyasa that stated pedagogical competence is the ability to manage the learning of learners includes an understanding of learners, instructional design and implementation, evaluation of learning outcomes, and the development of learners to actualize their potential. In addition, (Endang Asriyanti 143) define pedagogic competence is mastering cultural, emotional, and intellectual aspects. Pedagogic competence is mastering the theory of learning principles, developing curriculum, organizing the learning, using technology, information and communication in the learning process, communicating effectively and politely to the learners, conducting assessment and process evaluation and learning result, using the result of assessment and evaluation for the sake of learners and utilizing the results of assessment and evaluation for the sake of learning and taking the reflective action to improve the quality of learning.

\section{METHOD}

The method of this research is qualitative research with descriptive method. Creswell states that qualitative procedures demonstrate the different approach to scholarly inquiry than methods of 
quantitative research. For taking the data (Gay 204) stated that qualitative data collection is more than simply deciding observe or interview people. Five steps comprise the process of collecting qualitative data. The writer need to identify participants and sites, gain access, determine the types of data to collect, develop data collection forms, and administer the process in an ethical manner.

\section{RESULT AND DISCUSSION}

Based on the theory of research education by (Gay 465) data analysis in qualitative research involves summarizing data in a dependable and accurate manner and leads to the presentation of study findings in a manner that has an air undeniability. Qualitative data analysis requires that the researcher be patient and reflective in a process that strives to make sense of multiple data soures, inluding field notes from observations and interviews, questionnaires, maps, pictures, audiotape transripts, and videotaped observation. Technique of data analysis is the technique that used by the researcher in process of manages and organized the data that has analyzed.

\section{Data Validity}

According to (Fraenkel and Wallen 148) validity is the most important idea to consider when preparing or selecting an instrument for use. In addition, (Gay 391) written that in qualitative research, validity, is the degree to which qualitative data accurately gauge what the researcher is trying to measure.

The other theory also stated that qualitative validity means that the researcher checks for the accuracy of the findings by employing certain procedures, while qualitative reliability indicates that the researcher's approach is consistent across different researchers and different projects (Gibbs, 2007). The data has collected in this research, gathered through some of techniques, such as the observation's sheet that used by the writer to observe the process of teaching English, and then questionnaire that given to the English teacher, and the last process of interview that has done with the English teacher at SMK PGRI 3, and also some of students there. After the writer conducted these techniques to collecting data, the writer can gather and know the result of each of techniques that have done. Therefore, to verify the result of this research, it has been explained on the part of research findings and analysis. 
The ability of Teacher in The questionnaire use close ended mastering pedagogical competence questionnaire type with check list a. The Result of Questionnaire Sheet

$$
\text { The questionnaire }
$$

consists of the thirty of questions. form, that answered by the English teacher there. Thereby, the result of questionnaire sheet describes and explained as follow:

Table the Result of Questionnaire Sheet

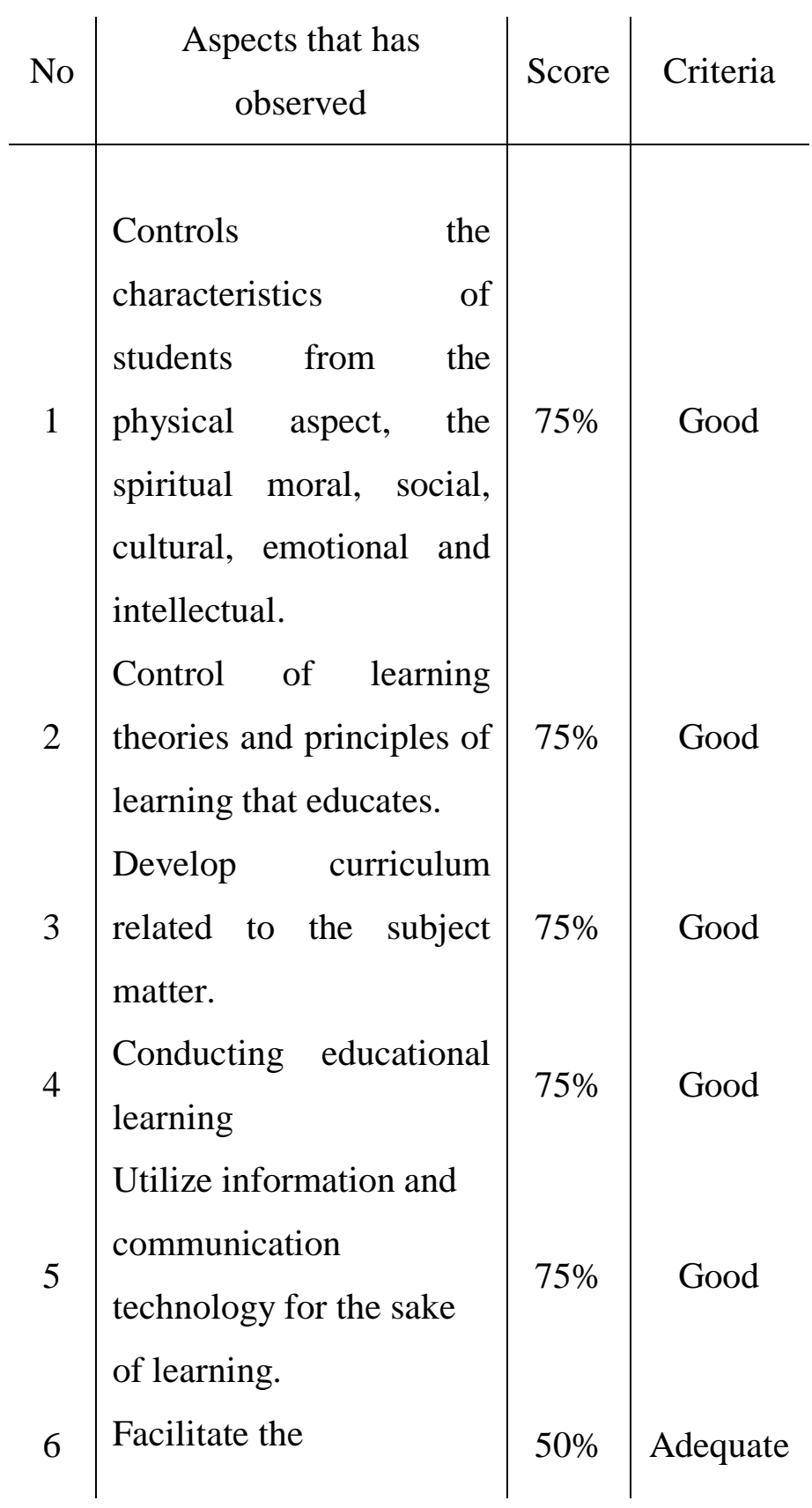




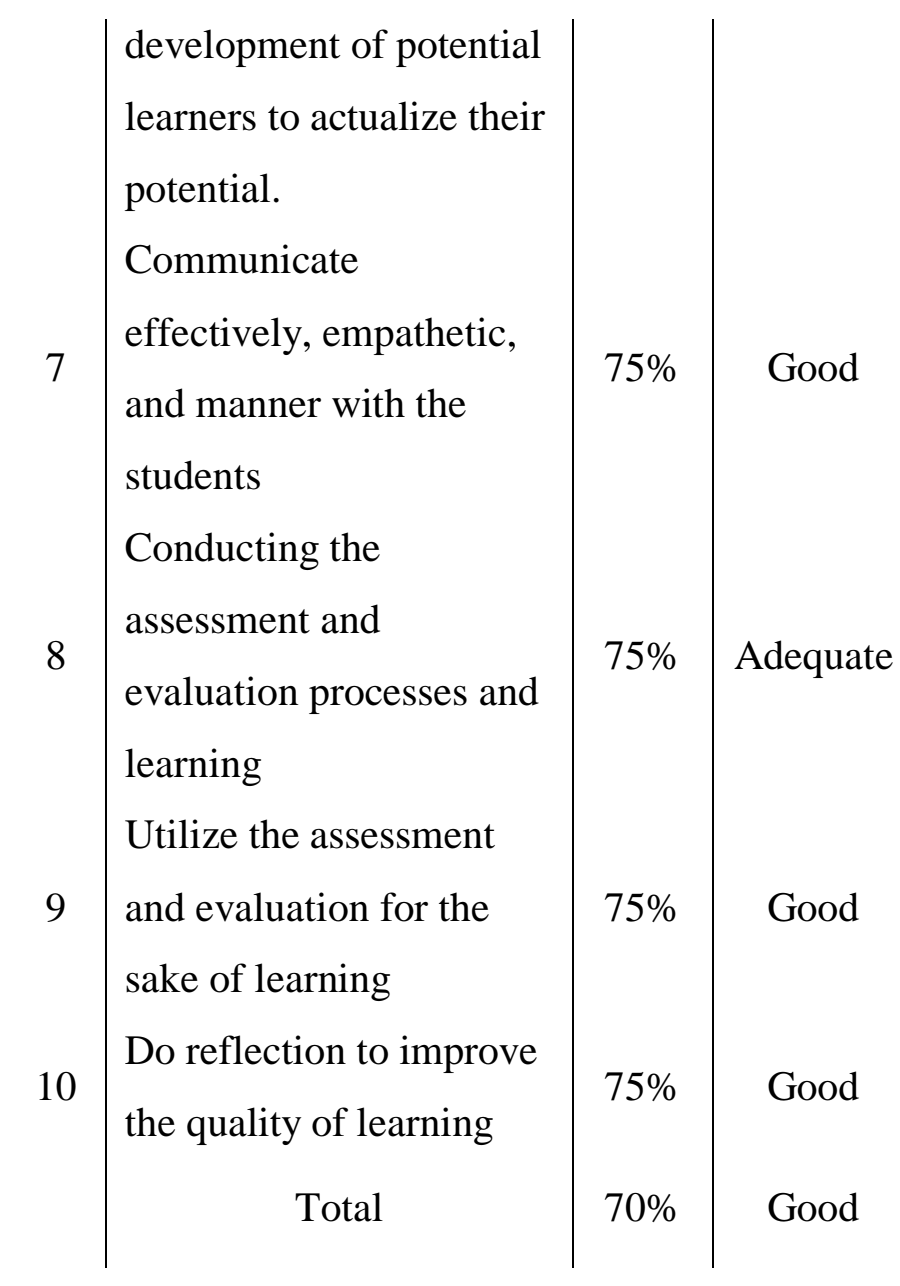

\section{The Result of Interview}

The interview has done with the three of English Teacher that being subject in this research. Interview conducted after the process of teaching and learning in the class. Not only with the English lecturer there, but the writer also interviewed some of students at SMK PGRI 3 Kota Serang. The kind of interview that used in this research is the personal interviews, and Process of interview conducted with the three of English teacher there. It consist of the $7^{\text {th }}$ questions that purpose to know the things that related to the pedagogical competence, especially in teaching English.

\section{The implementation of pedagogical competence in teaching English}

To answer the second formulation of problem in the first chapter, which it related to the implementation of 
pedagogical competence especially in teaching English, the writer use the data based on the result of observation sheet and interviewed some of students at SMK PGRI 3 Kota Serang. Which the result of observation sheet and interview with the students there was describe as follow:

\section{a. The Result of Observation}

The result of observation, describe and explain as below:

\section{Result of Observation Sheet}

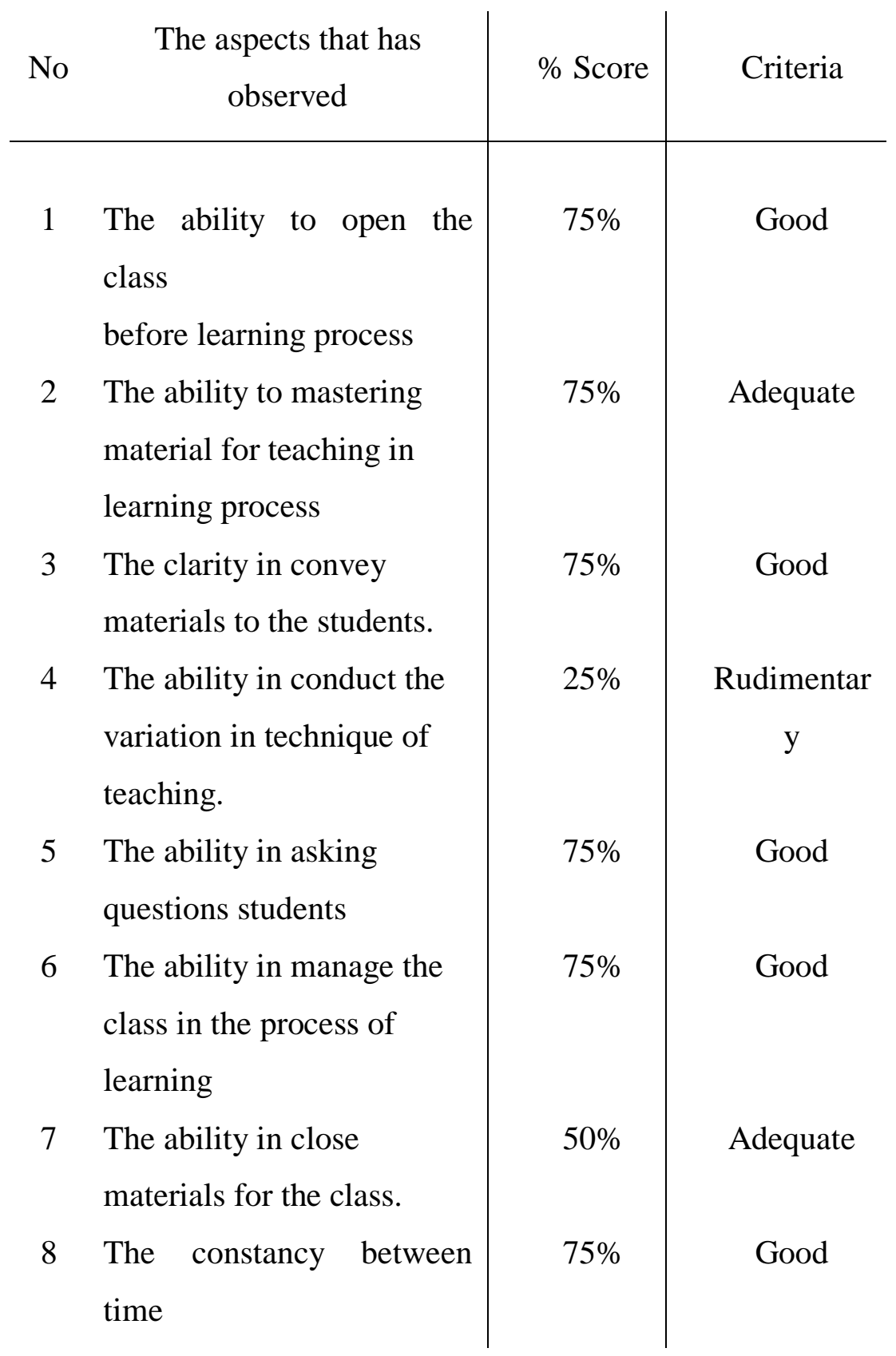


and materials of learning

Total

The Result of Interview with Students

In this research the writer also conducted process of interview with some of students. The questions that exist on this interview consist of $15^{\text {th }}$ questions, this interview have done with the five of students from the different classes that have observed. Based on the interview with students also stated that the teachers is rare to give assignment to the students, they tend to ask student to search and study the materials for next week. Or even ask students to do an exercise in form of questions, and then discuss it in the class. After students complete their assignment and if the time is over, it will be discuss in the next meeting.

\section{Analysis}

\section{Ability of Teacher in Mastering} Pedagogical Competence

There are two techniques that the writer used previously to know and describe the ability of teacher in mastering pedagogical competence, especially in teaching
Good
English. As the first, the questionnaire sheet, based on the questionnaire sheet it known that the ability of teacher in mastering pedagogical competence is good enough. The questionnaire sheet consist of thirty question which it contains the ten main indicators in pedagogical competence.

The result of questionnaire sheet that has totalled around $70 \%$ the ability of teacher in mastering pedagogical competence is good enough. It seen based on some of indicators on it get the good score. For controls the characteristic of students from physical aspects, the spiritual, moral, social, cultural, emotional and intellectual the score that calculate is around $75 \%$. It followed by the others aspect which have good score too, such as control of learning theories, conducting educational learning, develop curriculum related to the subject matter, utilize information and communication technology for the sake of learning, communicate 
effectively, empathic, and manner with the students, until conducting the assessment and evaluation process of learning, utilize it for the sake of learning, until the last do reflection to improve the quality of learning.

\section{The Implementation of Pedagogical Competence in Teaching English}

To know and describe process of implementation of pedagogical competence in teaching English, the writer conduct the observation and interview with some of the students at SMK PGRI 3 Kota Serang. Based on the result of observation sheet, it known that the effort that lecturer do to implement the pedagogical aspects in process of teaching English, is still include on the good criteria. Which, the result of average score shows around $8.55 \%$ for the process of implementation of pedagogical competence in teaching English.

\section{Conclusion}

1. Related to the indicator in pedagogical competence that written on Permendiknas No.16 Tahun 2007 , after conducted the research is known that the ability English teacher at SMK PGRI 3 Kota Serang in mastering the pedagogical competence is still include on the good category. It seen based on the ability in controls the characteristics of students, control of learning theories and principles of learning that educates, conducting educational learning, utilize information and communication technology for the sake of learning, facilitate the development of potential learners to actualize their potential, communicate effectively, empathetic, and manner with the students, conducting the assessment and evaluation processes and learning, utilize the assessment and evaluation for the sake of learning, until do reflection to improve the quality of learning has a good criterion.

2. For the implementation of pedagogical competence in teaching English it identified still on the good criterion for the process of teaching and learning. It seen from the way of teacher open the class before learning 
process, mastering material for teaching in learning process, manage the class in the process of learning, until the constancy between time and materials of learning also appropriate. Even though, still there are some of aspects that still on adequate and rudimentary category. But overall, after the writer totalled the whole of aspects, it can find that the process of implementation pedagogical competence in teaching English subject at SMK PGRI 3 Kota Serang is still good enough. It supported by the sheet of interview that have done with English teacher, and some of students that being subject in this research.

\section{References}

1. Armstrong, Thomas. Multiple Intelligences in the Classroom. 3rd ed. Virginia USA: ASCD publication, 2009. Print

2. Barkoska, Aneta. The Need of Strengthening the Pedagogical Competencies in Teaching from The English Teacher's Perspective. International Journal of Cognitive Research in Science, Engineering and
Education (IJCRSEE) 3 (2015): 43-44. Print

3. Beckman, Leslie Opp. and Klinghammer, Sarah J. Shaping the Way We Teach English: Successful Practices Around the World. United State of America: University of Oregon, 2006. Print

4. Broughton, Geoffrey. Teaching English as Foreign Language. New York: Rotledge, 2003. Print

5. Creswell, W. John. Research Design Qualitative, Quantitative, and Mixed Methods Approaches. USA: SAGE Publications, 2009. Print

6. Cresswell, W. John. Educational Research: Planning, Conducting, and Evaluating Quantitative and Qualitative Research. 4th ed. USA: Pearson, 2012. Print

7. Fraenkel. R. Jack., Norman E. Wallen, and Helen H. Hyun. How to Design and Evaluate Research in Education. 9th ed. New York: Mc Graw Hill, 2015. Print

8. Gage, L. Nathaniel. A Conception of Teaching. New York: Springer Science + Business Media. LLC, 2009. PrintGay, L.R,. Mills E, Geoffrey., and Peter Arasian. Educational Research : Competencies for Analysis. 10th ed. USA: Pearson Edition, Inc. 2012. Print

9. Glencoe. Reading with PurposeRubrics for Assessing Student Writing, Listening, and Speaking - Assessment - Middle School. New York: Mc Graw Hill, 2007. Print

10. Goodwyn, Andrew. And Branson, Jane. Teaching English. New York: Taylor \& Francis Group, 2005. Print 
11. Hakim, Adnan. "Contribution of Competence Teacher (Pedagogical, Personality, Professional Competence and Social) On the Performance of Learning." The International Journal Of Engineering And Science (IJES), 4 (2015): 1-12. Print.

12. Harmer, Jeremy. The Practice of English Language Teaching. 4th ed. United Kingdom: Ashford acaolour Press.Ltd, 2007. Print

13. Activities and Strategies for Creating a Multiple Intelligences Classroom. USA: Jossey Bass, 2010. Print

14. Indonesia. Dept. of Educational System. Undang-Undang Guru dan Dosen. Jakarta: Sinar Grafika, 2009. Print

15. Indonesia. Dept. of Educational System. Undang-Undang Sistim Pendidikan Nasional (SISDIKNAS). Jakarta: Permata Press, 2013. Print

16. Indonesia. Dept. of Educational System. Permendiknas No.16 Tahun 2007.

17. Maxom, Michelle. Teaching English as a Foreign Language For Dummies. England: John Wiley \& Sons, Ltd, 2009. Print

18. Munandar, Aris. And Sulistriyani. "Analisis Kompetensi Pedagogik Guru dalam Pembelajaran Sosiologi di Sekolah Menengah Pertama Negeri 1 Jawai." Journal of Education FKIP UNTAN, 2013. Print.

19. Nicholls, Gill. An introduction to Teaching. London: Taylor \& Francis Group, 2004. Print

20. Rasyidin, Waini. Pedagogik Teoritis dan Praktis. Bandung:
PT. Remaja Rosdakarya, 2014. Print

21. Richards, Jack C., and Rodgers, Theodore S. Rodgers. 2nd ed. Approaches and methods in Language Teaching. New York: Cambridge university press, 2006. Print

22. Riduwan., Sunarto. Pengantar Statistika. 8th ed. Bandung: Alfabeta cv, 2015. Print

23. Sugiyono. Metode Penelitian Kualitatif, Kuantitatif dan R\&D. 21st ed. Bandung: Alfabeta, 2014. Print

24. Suyanto, K.E Kasihani. English for Young Learners. 3rd ed. Jakarta: PT.Bumi Aksara, 2009. Print

25. Syahruddin, Ernawati, Andi., and Nasir Ede, Muh. "Teachers' Pedagogical Competence in School-Based Management: A Case Study in a Public Secondary School at Pare-Pare Indonesia." Journal of Education and Learning 7 (2013): 213-218. Print 
